April 2009

\title{
Ontological Destruction: Genocide and Canadian Aboriginal Peoples
}

Andrew Woolford

Follow this and additional works at: https://digitalcommons.usf.edu/gsp

\section{Recommended Citation}

Woolford, Andrew (2009) "Ontological Destruction: Genocide and Canadian Aboriginal Peoples," Genocide Studies and Prevention: An International Journal: Vol. 4: Iss. 1: Article 6.

Available at: https://digitalcommons.usf.edu/gsp/vol4/iss1/6

This Articles is brought to you for free and open access by the Open Access Journals at Digital Commons @ University of South Florida. It has been accepted for inclusion in Genocide Studies and Prevention: An International Journal by an authorized editor of Digital Commons @ University of South Florida. For more information, please contact digitalcommons@usf.edu. 


\title{
Ontological Destruction: Genocide and Canadian Aboriginal Peoples ${ }^{1}$
}

\section{Andrew Woolford Department of Sociology, University of Manitoba, Winnipeg}

\begin{abstract}
The impact of colonialism on Aboriginal groups in Canada is often described as "cultural genocide" or "ethnocide." In contrast, this article offers a re-reading of the United Nations Convention on the Prevention and Punishment of the Crime of Genocide (1948) that is sensitive to Aboriginal understandings and experiences of group life and group destruction. Through this re-reading, it is argued that genocide must be understood in a culturally contextualized manner so as to avoid modernist and Eurocentric biases. Only by opening up the conception of genocide will we be able to contend adequately with Canadian Aboriginal experiences of colonialism.
\end{abstract}

Keywords: genocide, Canadian Aboriginal peoples, residential schools, assimilation, cultural genocide

\section{Introduction}

The terms "cultural genocide" and "ethnocide" have often been used to describe the destruction perpetrated against Canadian Aboriginal peoples. ${ }^{2}$ In such cases, one senses that these terms are not intended to invoke one of the categories of genocide created by Raphael Lemkin when the United Nations Secretariat retained him in 1946 to help draft an international convention ${ }^{3}$ but, rather, are used as qualifiers to describe processes different from and less severe than genocide proper, which some suggest must involve the attempted physical annihilation of the targeted group. ${ }^{4}$ However, to characterize the harms produced by Canadian colonialism as cultural genocide is problematic on at least three grounds. First, the varied path of attempted Aboriginal destruction in Canada is misrepresented by attempts to reduce Canadian colonialism to a singular event and Aboriginal Canadians to a single "group." To put it simply, Canadian Aboriginal peoples are culturally and regionally diverse and experienced colonialism in different ways. Second, while all Aboriginal groups experienced at least some degree of attempted assimilation, some also experienced high levels of physical destruction through settler violence, disease, and deadly residential-school conditions, as well as biological interference with reproductive processes. Finally, the separation between "cultural" and "physical" forms of destruction-a modernist contrivance that contends that such neat categories in fact exist-collapses under a more detailed investigation of Aboriginal experiences of destruction. This third problematic is the primary focus of this article.

While the assumption that Canadian Aboriginal peoples experienced only cultural genocide is commonplace, in my research on land claims and reparations for Aboriginal peoples in British Columbia, I have come across many Aboriginal persons who describe their experiences of colonialism as "genocide." 5 At first, I took this to be a politicized use of the term-an attempt to harness its symbolic power to the task of advancing Canadian Aboriginal justice claims. ${ }^{6}$ Surely they meant cultural genocide or ethnocide. Moreover, in delineating their experiences of genocide, these Aboriginal respondents

Andrew Woolford, "Ontological Destruction: Genocide and Canadian Aboriginal Peoples" Genocide Studies and Prevention 4, 1 (April 2009): 81-97. (C) 2009 Genocide Studies and Prevention. doi:10.3138/gsp.4.1.81 
included not only residential schools and Canadian assimilation policies-phenomena often discussed under the rubric of cultural genocide-but also land appropriation, the spread of European diseases, and the broad legal framework of Canadian colonialism. Taking these claims seriously, I begin in this article from the premise that these people are neither strategically misinterpreting the term "genocide" nor employing it solely for political purposes. In doing so, I argue that a re-reading of the 1948 United Nations Convention on the Prevention and Punishment of Genocide (UNCG) through a lens sensitive to Aboriginal realities lends greater validity to these claims.

If we are to begin to address Canadian Aboriginal claims of genocide, it is necessary to reject a strictly epistemological approach to the question of genocide, one that seeks to identify a guiding legal or sociological definition of genocide that can be applied to multiple cases in a doctrinal manner. This means that the UNGC definition of genocide will not be used here as a "universal grid"7 for classifying human groups and their violent relations. Lost within such generalizations are local understandings of collective life and collective destruction. Thus, this article moves toward an "ontology of destruction," examining genocide from the perspective of how destruction is experienced and made sense of by targeted collectivities who define their worlds within culturally specific meaning systems. This portrayal will be partial, since it is impossible to do more than hint at some Aboriginal understandings of destruction within the allotted space. Thus, the examples provided are not intended as a comprehensive account of Canadian Aboriginal genocides but are merely illustrative of how the UNCG potentially fails to capture Canadian Aboriginal notions of being.

It should also be noted that my project is not to relativize or to broaden the concept of genocide to the extent that it loses all meaning. Instead, the UNCG will continue to serve as a guiding framework for constituting acts of genocide, but key components of its definition will be interrogated and opened up so that they move beyond modernist and Eurocentric meaning horizons. The goal is to employ the UNCG in a manner more sensitive to cultural specificity, rather than in a strictly legalistic sense. To this end, I will seek to destabilize what it means to be a "group," to show "intent," and to experience "destruction," all terms specified in art. 2 of the UNCG. ${ }^{8}$

\section{Aboriginal/Non-Aboriginal Relations in Canada}

Before embarking on this analysis it is necessary to provide a succinct summary of the history of Aboriginal/non-Aboriginal relations in Canada. The narrative that follows is a simplification of the process of colonization, which, as mentioned above, took a variety of distinct forms depending on the Aboriginal people and the region in question.

The first non-Aboriginal visitors to what is now Canada were Norsemen who attempted to settle parts of Newfoundland and Labrador in the eleventh century. Conflict ensued with the local Aboriginal population, and the Norse abandoned their efforts. In the latter part of the fifteenth century, Europeans returned, this time pursuing sea products ranging from cod to whale. Some expeditions set up temporary camps ashore to dry their catch, but, for the most part, they had minimal contact with Aboriginal peoples of this region.

Beginning in the sixteenth century, Europeans-in particular, the French and the British-set out more regularly to explore North America. At first they sought to discover a sea route to the riches of the Far East. But they soon discovered that North America possessed its own store of wealth: the beaver pelts and other animal furs that were desired in Europe. European traders depended on Aboriginal peoples to hunt and treat the furs so that they could be transformed into hats and other clothing. 
This trade continued through much of the seventeenth and eighteenth centuries, creating a symbiotic relationship between Aboriginal and non-Aboriginal trappers and traders.

Aboriginal peoples were also important military allies for the competing European colonizers. Warfare between Aboriginal peoples prior to the arrival of Europeans tended to produce few casualties, since the available weaponry was relatively unsophisticated. However, with the arrival of European military technology and the export of European struggles to North American soil, Aboriginal peoples found themselves increasingly engaged in deadly combat. The eighteenth century was particularly bloody as the French, British, and Anglo-Americans battled for control of North America. Many Aboriginal peoples found themselves immersed in war, whether as part of an alliance with one of the conflicting European nations or in combat with a new or long-standing Aboriginal enemy.

The French brought evangelism to their Aboriginal trading partners in the seventeenth century. These efforts to "save" the "souls" of Aboriginal peoples were intensified by religious orders such as the Récollets and the Jesuits who ventured into Aboriginal communities to proselytize to their inhabitants. These orders differed in the degree to which they sought to assimilate Aboriginal peoples to European ways. The Récollets attempted not just a spiritual but a cultural conversion, while the Jesuits believed that tending to the souls of Aboriginal peoples was enough. However, the presence of these and other evangelists within Aboriginal communities, not to mention the schools and churches they established, would, in the nineteenth and twentieth centuries, be used by the Canadian government in its attempts to culturally absorb Aboriginal persons into the Canadian mainstream (e.g., through "residential schools").

Despite the early presence of European traders and missionaries, settlers were few at the onset of Canadian colonization. Indeed, Aboriginal peoples would have been in a secure position to maintain their power, territories, traditions, and trade had it not been for the spread of European diseases. Since Aboriginal peoples had established little resistance to diseases such as smallpox, these diseases provided "biological power" to facilitate European control. ${ }^{9}$ Carried along trade routes, diseases often preceded Europeans into Aboriginal communities and decimated their populations. At least half the Aboriginal population of between 200,000 and 300,000 people was killed by disease between the beginning of the seventeenth century and the end of the nineteenth. ${ }^{10}$ This devastating death toll opened vast areas of land to European settlement and exploitation.

The destructive effect of colonialism intensified as Europeans began to seek possession of Aboriginal territories for settlement and resource exploitation. Once British control of Canada was established in the mid-seventeenth century, population pressures and land scarcity in Britain brought settlers seeking new economic opportunities to eastern Canada (and later to the Prairie region). In contrast, on the West Coast of Canada, various entrepreneurs spearheaded colonial control of what is today British Columbia when they strove to exploit the resources of this region. Colonial economic activities on the West Coast began with the fur trade but expanded into gold mining, fisheries, and forestry. Both settler and entrepreneurial patterns of colonization affected Aboriginal peoples drastically, carving their traditional territories into increasingly smaller allotments.

Any attempt by these newcomers to dispossess Aboriginal peoples of their lands was supposed to be constrained by British law. In the aftermath of the Anglo-French struggle for control of what is now Canada, George III of Britain issued the 
Royal Proclamation of 1763 to set the ground rules for colonial relations. The portion of this text that refers to Aboriginal peoples reads as follows:

We do therefore, with the Advice of our Privy Council, declare it to be our Royal Will and Pleasure ... that no Governor or Commander in Chief in any of our other Colonies or Plantations in America do presume for the present, and until our further Pleasure be known, to grant Warrants of Survey, or pass Patents for any Lands beyond the Heads or Sources of any of the Rivers which fall into the Atlantic Ocean from the West and North West, or upon any Lands whatever, which, not having been ceded to or purchased by Us as aforesaid, are reserved to the said Indians, or any of them. ${ }^{11}$

In accordance with this proclamation, the colonial government was charged with signing treaties with Aboriginal peoples through which the latter would exchange their territorial rights for goods and services to be provided by the Crown. This policy was followed in several parts of Canada, leading to the creation of agreements such as the "numbered treaties," which cover large portions of Ontario and the Prairie provinces. Negotiating in the afterglow of the cooperation and trust that defined the fur trade, Aboriginal groups often assumed the treaties to be living documents that would shift depending upon their changing needs. In contrast, the non-Aboriginal negotiators saw the treaties as an opportunity to restrict Aboriginal peoples to reserves and to gain access to their traditional territories through annuity payments. ${ }^{12}$

In other regions, this legal imperative to negotiate treaties was ignored. In British Columbia, for example, Aboriginal peoples were denied treaties and forced onto reserves smaller than those anywhere else in Canada. To this day, First Nations in British Columbia seek treaty agreements that will recognize their Aboriginal rights and title, as well as their inherent right to self-government. ${ }^{13}$

Although Canadian Aboriginal peoples have at times used laws such as the Royal Proclamation to pursue their Aboriginal rights and title, law has more often operated as a tool of colonization. Under British control, legal mechanisms such as the 1857 Gradual Civilization Act were passed to legislate the "progress" of Aboriginal peoples. Following Confederation in 1867, the Dominion of Canada increased its use of law as a means to control Aboriginal peoples. Indeed, a first step in this control was to define the population that was to be controlled. In 1876, the Indian Act officially codified the definition of Indian and non-Indian. ${ }^{14}$ This piece of legislation, despite many revisions, is still in place and still regulates most dimensions of the lives of First Nations individuals and communities. ${ }^{15}$ In addition, traditional Aboriginal government structures were reshaped through laws such as the Indian Act and the Enfranchisement Act of 1869, which combined to give the Canadian government greater powers to interfere with governance on Aboriginal reserves.

It should also be noted that the spread of Canadian policing to the far corners of the new nation had a marked impact on Aboriginal ways of life. Royal North-West (later Canadian) Mounted Police officers enforced Canadian law upon even those Aboriginal peoples who had previously operated at some remove from the colonial government. Among the most destructive laws were those forbidding traditional cultural practices, such as the Potlatch or Sun Dance, and those that required Aboriginal children to attend residential schools. ${ }^{16}$

Residential schooling was an important part of a broader policy of assimilation. Frustrated by Aboriginal peoples' refusal to accept Canadian offers of "enfranchisement," Canadian leaders turned to education as a means to eliminate Aboriginal cultures. Residential schools began operating in the late nineteenth century, drawing on an existing network of Protestant and Catholic schools. These were initially day 
schools, but their administrators felt that the children's returning to their parents at the end of each day was undoing their day of lessons in the proper conduct of "civilized" persons. In response, the schools began to hold students in residence for most of the year, giving them only a month in the summer to visit their families. By 1920, residential schools were made mandatory for all Aboriginal children. At many schools, conditions were so inadequate that large numbers of children died from ill health, exposure to the elements, and poor nutrition. ${ }^{17}$ Others suffered physical and sexual abuse, as well as a constant verbal assault on their cultures, traditions, communities, and families. Upon completing their education, many no longer felt at home or welcome in their communities and became divorced from their cultural traditions. Moreover, deprived of the experience of being parented, they later found it a great struggle to raise their own children. ${ }^{18}$ Continuing cycles of emotional, physical, and sexual abuse, as well as addiction, suicide, and other markers of intergenerational trauma, within Aboriginal communities are considered residual effects of the residential-school experience. ${ }^{19}$

The combined effects of land appropriation, violated or ignored treaties, legal domination, and forced assimilation were devastating for Aboriginal peoples. However, they did not entirely succumb to these experiences. Since colonization they have enacted resistance both on an everyday and at a broader societal level. On the everyday level, Aboriginal peoples have held onto their identities and have worked hard to recover and revitalize Aboriginal languages and traditions in order to preserve their cultures. Although these emblems of cultural identity are still in jeopardy, the extent to which they have survived is remarkable, given the colonial onslaught against them. ${ }^{20}$ On a broader societal level, Aboriginal persons have used national political organizations such as the Assembly of First Nations and countless regional bodies to express Aboriginal grievances and to pursue justice. The efforts of such organizations have culminated in several moral and political victories. For example, in 1969, the Canadian government tabled a white paper through which it attempted to impose the individual rights of Canadian citizenship upon Aboriginal persons. This policy decision, taken by Pierre Trudeau's Liberal government, seemed so contrary to advice provided by First Nations leaders in government consultations prior to the release of the document that it immediately galvanized Aboriginal persons across Canada. Most saw this policy as an attempt at cultural assimilation that would destroy the Aboriginal way of life. Because of their vocal and concerted protest, the Trudeau government was forced to withdraw the proposal.

Aboriginal peoples have also used Canadian courts to protect and extend their Aboriginal rights and title. One of the first major legal victories for Aboriginal peoples came in Calder v. British Columbia (1973). ${ }^{21}$ Although the Supreme Court of Canada's decision did not technically favor the Nisga'a First Nation, which launched the case, the reasons for the judgment given by the Court did recognize that Aboriginal title is not something granted by the Crown but, rather, pre-exists European settlement. This decision, together with Aboriginal protests against the 1969 white paper, convinced the Canadian government to take steps to acknowledge Aboriginal demands. In this spirit, in 1974 the government began to negotiate comprehensive land claims with Aboriginal groups that did not possess treaties, and affirmed and recognized Aboriginal and treaty rights in Part II of the Constitution Act, $1982 .^{22}$

Aboriginal peoples remain a powerful force within Canadian society, despite living in conditions that set them apart in terms of poverty, health, economic opportunity, education, and other indicators of social marginalization. 


\section{Genocide and Canadian Aboriginal Peoples}

The complexity of this historical narrative, even in such a simplified form, makes any application of the concept of genocide to the circumstances difficult. First, the events described above are loosely networked and do not follow any straightforward genocidal teleology of intent; that is, although we see many moments of intentional destruction, it would be difficult to legally prove the existence of a focused plan of annihilation that could be construed as specific intent. Second, assaults on Aboriginal peoples often derived from what were, at least at the time, liberal or even humanistic motivations. Various "enlightened" Europeans came to North America with the belief that "Indians" could - through instruction and education-be made fit for "civilized" society. Finally, given the constant presence of Aboriginal resistance, there is a tendency in Canadian historiography to avoid use of the term "genocide" lest it portray Aboriginal nations as utterly powerless in the face of European might and overlook their impressive perseverance. $^{23}$

These issues must be acknowledged in addressing Canadian Aboriginal claims of genocide. However, they also distract us somewhat from grappling directly with Aboriginal experiences of attempted colonial destruction. The first two issues prioritize the intentions and motives of the perpetrators, but we must first address what we mean by "destruction" before we can examine whether or not it was intended. As I suggest below, Aboriginal peoples who suffered greatly at the hands of the majority continue, in their own eyes, to suffer the effects of colonialism. Humanitarian motives do not absolve genocidal intent if these humanitarian beliefs promoted the denial and elimination of Aboriginal ways of being. The third issue attempts to shift the focus away from portraying Aboriginal peoples as passive victims and toward an emphasis on their active survival; however, it is wrong to assume that charges of genocide presuppose the passivity of victims. Indeed, one would be hard pressed to find any instance of genocide that did not meet with some level of resistance on the part of victims.

The remainder of this article is devoted to re-reading the opening sentence of art. 2 of the UNCG in a manner informed by Canadian Aboriginal experiences of colonialism. The objective is to illustrate how we must first open our evaluative tools to localized Aboriginal understandings of group identity and collective destruction before we can attempt to adjudicate whether or not genocidal intent was evident in the Canadian case.

\section{Genocide and the UNCG}

Raphael Lemkin devised the term "genocide," a combination of Greek genos ("race," "tribe") and Latin cide (from cidere, "to kill"), to provoke the world to take seriously this crime that had heretofore gone "without a name." ${ }^{24}$ With this new word in hand, he directed his efforts toward the legal codification of the term so that a clear standard would be in place, rather than the hodgepodge of international treaties and agreements that did not speak to the scale of genocidal crimes. Debate continues about what Lemkin determined to be included within, or necessary to, his definition of genocide.

Lemkin, with his focus on the maintenance and protection of "national groups," discussed not only mass killing and the physical elimination of such groups but also what is often referred to as "cultural genocide" or "ethnocide." ${ }^{25}$ Some, such as Ward Churchill, argue that, according to Lemkin, the destruction of a group's ability to continue its cultural existence is sufficient for a determination of genocide. ${ }^{26}$ 
Others argue that Lemkin still held killing to be an essential component of genocide. ${ }^{27}$ Regardless, it is important to note that Lemkin did give priority to the protection of cultural or "national" groups. ${ }^{28}$ Thus, "physical" genocide was not, for him, simply a matter of individual killings in the aggregate; rather, it referred to the manner in which the mass loss of life debilitates the continuation of a "group." Given this, it must also be acknowledged that extermination is not the only means available to achieve group destruction, although it is certainly a potent and primary means.

Moreover, we must first learn something about the group's singularity, or what Lemkin calls the "essential foundations" of group life, ${ }^{29}$ if we are to ascertain what it might mean to destroy them. What binds the group together? What cultural components are central to the definitional work of reproducing this group as a social unit? Obviously, there must be individual members participating in this collectivity if it is to exist, but there may be other necessary factors involved as well: territory, language, modes of governance, to name but a few. Based on this focus on the key components of group life, the analytical difference that scholars such as Chalk and Jonassohn claim to exist between physical and cultural forms of genocide becomes less obvious, as we can envision the possibility that the loss of the so-called cultural components of group life might be as damaging to the group's sustainability as the killing of its members. ${ }^{30}$ Thus, these processes of physical and cultural destruction are so entwined that they are often separable only at an analytical level that breaks down upon examination of actual experiences of destruction. ${ }^{31}$

Lemkin's goal of achieving recognition of the crime of genocide was realized, in part, with the drafting of UNCG. Article 2 of this convention reads,

In the present Convention, genocide means any of the following acts committed with intent to destroy, in whole or in part, a national, ethnical, racial or religious group as such:

(a) Killing members of the group;

(b) Causing serious bodily or mental harm to members of the group;

(c) Deliberately inflicting on the group conditions of life calculated to bring about its physical destruction in whole or in part;

(d) Imposing measures intended to prevent births within the group;

(e) Forcibly transferring children of the group to another group. ${ }^{32}$

Setting aside for the moment the five means to genocide that follow the "as such," as well as the political context in which this article was crafted, ${ }^{33}$ it is worth exploring the opening sentence of art. 2 in relation to Canadian Aboriginal experiences of destruction. It is this statement that establishes the parameters of the UNCG, demanding that we consider the meanings of words such as "intent," "destroy," and "group."

\section{Aboriginal Understandings of Group Identity}

One of the most controversial aspects of the UNCG is that it restricts the groups potentially targeted by genocide to "national, ethnical, racial or religious" groups. Clearly, this is a rather limited list of potential groupings that ignores a great variety of forms of collective life. ${ }^{34}$ Nonetheless, it could be argued that Aboriginal groups fit into one or more of these group categories. For example, Aboriginal groups have some of the characteristics of racial or ethnic groups, in the sense that they exhibit distinct cultural practices and are bound by specific norms, beliefs, and a common language or 
linguistic heritage. However, this designation overlooks the multiethnic dimensions of Canadian Aboriginal communities. Often these communities invite members from other communities to join their ranks; indeed, such ethnic mobility was historically encouraged as a means of creating inter-tribal links. ${ }^{35}$ For this reason, one might be tempted, instead, to designate Canadian Aboriginal communities as "nations" for purposes of the UNCG. However, this too is imperfect, since, unlike European notions of nationhood that presuppose fixed national boundaries, Aboriginal understandings of territory tend to be more fluid. For example, neighboring Aboriginal groups often held "shared territories" that allowed for multi-community usage of lands. ${ }^{36}$

Thus, the restrictions placed on group identity by the UNCG are inappropriate and potentially encourage a "totalization" of community life that is itself a danger to Aboriginal group identities. In other words, by seeking to impose clear community parameters upon Canadian Aboriginal groups, interpreters of the UNCG may miscategorize these communities in a way that obstructs their attempts to exist as "becoming communities" process of self-definition and redefinition that never suggests a point of community closure. Indeed, some Aboriginal peoples consider the experience of enforced closure, through mechanisms such as the Canadian reserve system and the "self-governance" arrangements offered by the Canadian government, part of an ongoing process of attempted colonial destruction. ${ }^{38}$

The UNCG further implies that a group consists solely of its human members, but this may be quite contrary to the group identity of collectivities adhering to or built upon animist belief systems that include their environs and local wildlife as part of the group. Under the terms of the UNCG, the impact of the destruction or expropriation of lands and wildlife on group life is considered only through the charge (in art. 2(c)) of "deliberately inflicting on the group conditions of life calculated to bring about its physical destruction in whole or in part." Indeed, several scholars have used this part of the UNCG to argue that the ecological destruction experienced by Canadian Aboriginal peoples is genocidal. ${ }^{39}$ Along these lines, one could examine how, at the end of the fur-trade period, with the move toward settlement, the colonial project began to bear more directly on Aboriginal lands. For example, in British Columbia, the imposition of the reserve system denied Aboriginal peoples nearly all of their territories, as well as traditional hunting, fishing, and governance practices. As Cole Harris notes,

From the late $1860 \mathrm{~s}$, Native leaders had protested their small reserves in every way they could, claiming, fundamentally, that their people would not have enough food and that their progeny had no prospects. In retrospect, they were right. The spaces assigned to Native people did not support them, although the mixed economies they cobbled together, the revised diets they ate, and the accommodations and settlements they lived in had allowed some of them to survive. ${ }^{40}$

This destructive force of colonial land appropriation is evident in the experiences of the Tsawwassen First Nation. Located in the lower mainland of British Columbia, their reserve was wedged between a ferry terminal, a coal port, and a highway. The coal port and the ferry terminal combined to destroy shellfish life and fishing areas along the Tsawwassen beachfront, and their longhouse was destroyed to make way for the highway. Such practices, and their equivalents throughout BC and across Canada, ${ }^{41}$ were near catastrophic in their consequences, especially when combined with the population loss caused by European diseases, making difficult not only cultural but also physical reproduction. Thus, one could reasonably argue that these 
are instances in which "conditions of life calculated to bring about [an Aboriginal group's] physical destruction in whole or in part" were inflicted.

However, this reading does not fully address the centrality of land and wildlife to Aboriginal peoples. As Peter Kulchyski suggests of Aboriginal communities in Denendeh and Nunavut, the Aboriginal relationship to landscape is neither merely "closeness" to nor a strong reliance upon nature; rather, the natural world represents an "embodied inscription." 42 Territory is an essential part of their group-formation processes, and its removal represents a dire threat to the ability of these groups to reproduce a group identity. Mohawk legal scholar Patricia Monture-Angus describes group identity as follows: "Identity, as I have come to understand it, requires a relationship with territory (and not a relationship based on control of that territory)."43 The point is that it is a disservice to force Aboriginal experiences of ecological destruction into a framework that acknowledges only the subsistence value of land to a group, even if this move might initially appear to advance their justice claims by clearly locating land and wildlife destruction within the terms of the UNCG. To fully acknowledge the Aboriginal experience of attempted destruction, we need to understand land and environment not simply as means of sustaining group life, but as key components of group life. Thus, in our example, the Tsawwassen did not simply lose their traditional food supports and their longhouse; the whittling down of their reserve and the destruction of their sociocultural environment placed severe restrictions on how they could imagine themselves as a people in relation to, and as part of, their physical surroundings.

Similarly, Westphalian notions of "national" territory as bounded property to be owned and used for profit often conflict with traditional Aboriginal understandings of territory. ${ }^{44}$ For the Coast Salish of British Columbia, territories are not sharply defined and instead allow for greater freedom of movement, sharing, and relationships. Indeed, the imposition of boundaries upon these communities presents a significant challenge to their self-understandings and group identity. As Brian Thom states, Coast Salish members

see boundaries and borders as arbitrary and artificial at best, and at worst a part of a recurring colonial mechanism of government to create division between communities and kin and weaken the potential strength of the Coast Salish people as a Nation. These people are concerned that the power of such maps and terms will have the effect of severing their connections to place, framing the future of engagements with the land exercised as rights negotiated under land claims settlements firmly in western ontological terms. ${ }^{45}$

Genocide scholars interested in the attempted destruction of Canadian Aboriginal peoples should thus be wary of trying to categorize and draw boundaries around these peoples in a manner that imposes Western understandings of group identity and group spaces. If its categories are not held sufficiently open to Canadian Aboriginal notions of identity and space, the UNCG may unwittingly become yet another Eurocentric tool for reframing Aboriginal lifeworlds, rather than a resource for Aboriginal justice. ${ }^{46}$

\section{Forms of Destruction}

So what does it mean to "destroy" a group? The previous section discussed the destructive effects of the imposition of European notions of group identity and territory; in this section I focus instead on how a modernist framing of destruction potentially leads to the exclusion of certain harms from consideration in our discussion of genocide. 
Genocide carries with it notions of harm that are artifacts of a specific (in particular, modernist) viewpoint that may not reflect how harms are experienced and understood by different collectives. This is particularly true of what are argued to be "natural" processes of destruction, such as disease and famine. As Bruno Latour notes, the modern "Constitution" holds the poles of nature and culture separate, all the while allowing for the proliferation of hybrids, or "quasi-objects" and "quasi-subjects," that are amalgamations of nature and culture networked together in a complex interface. This act of "purification"- that is, of keeping nature and culture separateallows moderns to stack the deck in their favor, designating events and objects to either the nature or the culture pole when it suits their interests. ${ }^{47}$ Taking Latour's argument out of its science studies context, we can examine how this practice of purification operates within debates about what is and what is not genocide, as the hybridity of destructive processes-for example, the deadly spread of HIV/AIDS through rapes, or the destruction caused by (fully or partially) orchestrated famines designed to punish rebellious collectives-often complicates the picture of what is and is not a part of a genocidal action.

We are able to separate hybridic and networked phenomena such as disease and famine into the category of "nature" (as distinct from culture or society) not because this is what empirical evidence suggests but because we adhere to an intellectual orientation that holds nature and culture to be mutually distinct and uncoupled, despite their clear interconnections. ${ }^{48}$ Moreover, this separation also allows for the production of more terrible hybrids whose destructive tendencies are not held to account by law or ethics because they are not viewed as targets for social intervention. Thus, European diseases were permitted to ravage Aboriginal communities largely unchecked, and with a certain degree of indifference, because these were not processes for which Europeans felt particularly responsible. ${ }^{49}$

The spread of European diseases served to weaken Aboriginal communities and to increase European dominance in North America. As traders and missionaries penetrated further into Aboriginal societies, they carried epidemics such as smallpox with them. In other cases, the diseases spread through Aboriginal networks, originating at colonial entry points-the forts and ports of North America-and eventually reaching even those groups who had yet to experience European contact. In these latter cases, the diseases acted as a pre-emptive form of ethnic cleansing, allowing Europeans to declare Aboriginal lands terra nullius upon reaching the latter's decimated communities. ${ }^{50}$

Amidst the first epidemics of the mid- to late seventeenth century, the growing importance of trade for Aboriginal societies limited their ability to respond to the simultaneously growing threat of disease. For example, the Huron in southwestern Ontario suspected that the plagues that were destroying their communities were brought by the French Jesuit missionaries, but they dared not evict the missionaries for fear that the French would halt trade with the Huron. Subsequently, with the Huron weakened by disease and the supply of beaver pelts dwindling to the point of provoking greater inter-tribal friction over trade competition, the Iroquois confederacy attacked and destroyed the Huron. ${ }^{51}$

Tuberculosis was rampant through many residential schools until the 1940s, and reports suggest that the staff at these schools did little to help the infected children. Susceptibility to this and other diseases was increased by the poor nutrition and inadequate clothing provided to students. In addition, there are reports of students' being required to bunk with others who were infected. ${ }^{52}$ With death tolls from 
tuberculosis reaching as high as 50\% in some schools, any claim that this was simply "natural" is exposed as disingenuous at best.

More recently, the community of Grassy Narrows experienced the destructive effects of forced modernization, environmental deterioration, and assimilation. Relocated from their more isolated reserve by the Canadian government because it was believed the First Nation would be better served if they had access to a direct roadway to Kenora, Ontario, the community suffered in the end through the loss of its traditions, mass suicide, rampant child neglect and abuse, widespread alcoholism and mercury poisoning, and the destruction of their food source and livelihood. ${ }^{53}$

Each of these destructive events represents a braiding of social and natural processes. ${ }^{54}$ However, the UNCG is often read within a modernist framework that assumes a stark divide between nature and culture. Thus, the five forms of destruction highlighted in art. 2-"killing members of the group; causing serious bodily or mental harm to members of the group; deliberately inflicting on the group conditions of life calculated to bring about its physical destruction in whole or in part; imposing measures intended to prevent births within the group; forcibly transferring children of the group to another group"-all presume a decidedly social strategy of elimination. The problem with this presumption, in terms of understanding the attempted destruction of Canadian Aboriginal peoples, is that it allows the colonizer to avoid responsibility for hybridic assaults on Aboriginal peoples. Disease is conveniently removed as relevant evidence because it is classified as a natural process. But diseases such as smallpox and tuberculosis, and industrial ailments such as mercury poisoning, were experienced by Aboriginal peoples as consequences of enforced contact with non-Aboriginal peoples, and as part of a structured set of destructive relations, that cannot simply be categorized as "natural." If we are to contend adequately with these experiences, we must not exclude certain forms of destruction from consideration; instead, genocide scholars must be ready to interrogate the modernist oppositions that shape our ways of knowing and being in the world.

\section{Understanding Intent}

One of the most vexing issues in discussions about genocide in Canada is that of intent. As in debates about genocide in other settler societies (the United States, Australia, and New Zealand), questions are raised about whether the perpetrators clearly formulated an intent to eliminate Aboriginal peoples. Some argue that because the Canadian colonial government's assimilation policies were based on humanitarian and welfare-oriented concerns, they cannot be considered genocidal, since they do not evince a clear malevolent intent. Others point to the fact that functionaries and settlers operating at a distance from government were often the key agents of Aboriginal destruction. Missionaries, gold miners, settlers, and others carried with them no government mandate to impinge upon Aboriginal lifeworlds. However, Lemkin's work on Aboriginal genocides suggests that centrally coordinated planning is not required for an event to be categorized as genocide. Indeed, Lemkin's work shows great awareness of the networked character of Aboriginal destruction, acknowledging that various "genocidists" possessing different motives might each play a role in the wider process of Aboriginal destruction. ${ }^{55}$

My objective in this section, however, is neither to outline debates about colonial intent nor to offer an alternative notion of intent. Rather, I aim to demonstrate, through the example of Canadian residential schools, how the notion of intent hinges on our understandings of group identity and group destruction. ${ }^{56}$ In other words, 
unless we take Aboriginal notions of group identity and group destruction seriously, we will have difficulty pinpointing "intent."

Death was not an uncommon event in Canada's residential schools. More than half the students at certain schools succumbed to early death from unchecked disease, poor nutrition, or lack of proper clothing and shelter. ${ }^{57}$ Add to these the deaths brought on through physical and sexual assaults, and the suicides that sometimes followed these attacks, and one gains a sense of the deadly nature of this "civilizing" project. The point has been made that it was the "progressives" of their time who sought to redeem Aboriginal peoples by incorporating them into colonial society. ${ }^{58}$ For this reason, charges of presentism are often leveled against those who are insensitive to the ethical milieu in which government and residential-school workers operated. Indeed, in the words of Reverend Wilson of the Shingwauk, residential schools appear benign on the surface:

[The Indian child] must be taught many things which come to the white child without the schoolmaster's aid. From the days of its birth, the child of civilized parents is constantly in contact with the modes of civilized life, of action, thought, speech and dress; and is surrounded by a thousand beneficent influences.... He [the Indian child] must be led out from the conditions of ... birth, in his early years, into the environment of civilized domestic life; and he must be thus led by his teacher. ${ }^{59}$

The intention to breach the bond between parent and child and to disconnect the Aboriginal child from his or her collective receives much more blatant treatment in the words of Duncan Campbell Scott, superintendent of Indian Affairs from 1913 to 1932: "I want to get rid of the Indian problem. Our object is to continue until there is not a single Indian in Canada that has not been absorbed. They are a weird and waning race." 60 Those seeking a teleology of intent would likely identify the latter statement as a point of origin in the Canadian genocidal process, but we must not fall into this trap; instead we should seek to understand the networked destruction wrought by residential schools in Canada as they destroyed not just lives but generations of lives by disrupting cultural patterns of parenting and cultural transmission. In this sense, they reflect an all-out assault on Aboriginal ontologies. As John Milloy points out,

The child, parent, and community exist in a landscape-a culture's translation of environment into a "meaning"-filled place. Parts of the programme of studies would disorient children and then attempt to re-orient them in a place filled with European "meaning." This "programme" intersected with other parts of the Canadian colonial enterprise to drastically alter the path of Aboriginal cultural production and reproduction. ${ }^{61}$

Thus, even though we have what may be taken as a clear statement of intent issued by a prominent government official, an overreliance on this statement distracts us from what is really at stake here: a colonial project that refused, and continues to refuse, to recognize the legitimacy of Aboriginal lifeworlds. Canadian colonialism has sought - through a range of seemingly benign and overtly aggressive actions-to replace these lifeworlds with the cultural patterns of the colonizers. ${ }^{62}$ As Robert van Krieken states with respect to the experiences of the "stolen generations" of Australian Aboriginal peoples, the source of destruction may lie less in an "unambiguous 'intent to destroy' a human group, than in the presumption that there was not much to destroy."63 Thus, to better understand the Aboriginal experience of destruction, we must move beyond a legalistic notion of intent that seeks to identify specific calculations of destruction on the part of the perpetrator; instead, we must understand intent as a catastrophic form of misrecognition, which so devalues a population that 
assimilation is assumed to be a matter of their general welfare. In many ways, Europeans imagined Aboriginal peoples to be destitute, backward, uncivilized, and savage, and these assumptions facilitated their choice to impose a "liberal humanism" that denied Aboriginal ontologies.

\section{Conclusion}

The argument that Canadian Aboriginal peoples have experienced genocide is not new. ${ }^{64}$ However, the authors who make this argument tend to take a universalist and modernist interpretation of genocide as their premise and to fit their claims of genocide within its frame, thereby reinforcing its hegemony. In contrast, my objective here has not been to prove a Canadian Aboriginal genocide against the UNCG standard or any other; instead, I have attempted to (a) establish that the designation of "cultural genocide" is too qualified and imprecise for understanding Canadian Aboriginal experiences of colonialism, and (b) argue that re-reading and opening certain components of the UNCG through an engagement with Canadian Aboriginal experiences and understandings of group identity, destruction, and intent provides a clearer path to discerning the nature of genocide in Canada.

\section{Notes}

1. According to the Canadian Constitution, the Aboriginal peoples of Canada are the Indians, Inuit, and Métis. Constitution Act, 1982, s. 35(2), being Schedule B to the Canada Act 1982 (U.K.), 1982, c. 11. "Indians" is the term used to refer to the many "First Nations" persons defined as either "status" or "non-status" by the Indian Act, R.S.C. 1985, c. I-5. "Inuit" means "people" and refers to a set of culturally similar indigenous groups who reside in Canada's north (the term is also used to describe non-Canadian indigenous peoples). The Métis are people of mixed First Nations and European descent. Much of the information drawn on in this paper focuses on First Nations peoples in Canada, but I use the more general term "Aboriginal" because Inuit and Métis have shared many of these experiences.

2. J. Rick Ponting and Robert Gibbons, Out of Irrelevance: A Sociopolitical Introduction to Indian Affairs in Canada (Toronto: Butterworth, 1980), 18; Terry Wotherspoon and Vic Satzewich, First Nations: Race, Class and Gender Relations, 2nd ed. (Saskatoon: Canadian Plains Research Center, 2000), 28.

3. The other two categories are "physical genocide" (the "outright extermination or imposition of slow death measures") and "biological genocide" ("the prevention of births among the target group"). The category of "cultural genocide," in contrast, refers to the "destruction of the specific characteristics of the group." Ward Churchill, "Forbidding the 'G-Word': Holocaust Denial as Judicial Doctrine in Canada," Other Voices 2, no. 1 (2000), http://www.othervoices.org/2.1/churchill/denial.html\#53b (accessed 19 December 2008).

Churchill argues that these three categories are of "equal gravity" and do not represent a hierarchy of harm.

4. Frank Chalk and Kurt Jonassohn, The History and Sociology of Genocide: Analyses and Case Studies (New Haven, CT: Yale University Press, 1990), 23.

5. Andrew Woolford, Between Justice and Certainty: Treaty-Making in British Columbia (Vancouver: UBC Press, 2005).

6. For discussion of the potential banalization of genocide see Helen Fein, "Genocide: A Sociological Perspective," in Genocide: An Anthropological Reader, ed. Alexander Laban Hinton, 74-90 (Malden, MA: Blackwell, 2002), 74; Michael Ignatieff, "Lemkin's Word: The Danger of a World Without Enemies," The New Republic, 26 February 2001, 25-28.

7. Charles L. Briggs and Clara Mantini Briggs, “The Indians Accept Death as a Normal, Natural Event': Institutional Authority, Cultural Reasoning, and Discourses of Genocide in a Venezuelan Cholera Epidemic," Social Identities 3 (1997): 439-69, 460. 
8. Convention on the Prevention and Punishment of the Crime of Genocide, 9 December 1948, 78 U.N.T.S. 277, http://www.unhchr.ch/html/menu3/b/p_genoci.htm (accessed 19 December 2008), art. 2.

9. Michael Mann, The Dark Side of Democracy: Explaining Ethnic Cleansing (Cambridge: Cambridge University Press, 2005).

10. J.R. Miller, Skyscrapers Hide the Heavens: A History of Indian-White Relations in Canada, rev. ed. (Toronto: University of Toronto Press, 1989).

11. George R., Proclamation, 7 October 1763 (3 Geo. III), reprinted in R.S.C. 1985, App. II, No. 1. The text of the Royal Proclamation is also available online through the Virtual Law Office, http://www.bloorstreet.com/200block/rp1763.htm (accessed 20 December 2008).

12. Arthur Ray, Jim Miller, and Frank Tough, Bounty and Benevolence: A History of Saskatchewan Treaties (Montreal: McGill-Queen's University Press, 2000). It should be noted that the terms of these treaties are contested and that many Aboriginal groups argue that the terms have been violated. Alleged treaty violations are dealt with through the Canadian government's "specific claims" process, whose current backlog of claims would likely take well over a century to resolve at the current pace.

13. Woolford, Between Justice and Certainty.

14. George Manuel and Michael Posluns, The Fourth World: An Indian Reality (Don Mills, ON: Collier-Macmillan., 1974).

15. Brian Calliou and Cora Voyageur, "Aboriginal Economic Development and the Struggle for Self-Government," in Power and Resistance: Critical Thinking about Canadian Social Issues, 2nd ed., ed. Wayne Antony and Les Samualson, 115-34 (Halifax: Fernwood Publishing, 1998); Dara Culhane, The Pleasure of the Crown (Vancouver: UBC Press, 1997).

16. Christopher Bracken, The Potlatch Papers: A Colonial Case History (Chicago: University of Chicago Press, 1997); Douglas Cole and Ira Chaikin, An Iron Hand Upon the People: The Law Against the Potlatch on the Northwest Coast (Vancouver: Douglas \& McIntyre, 1990).

17. Kevin Annett, Hidden from History: The Canadian Holocaust: A Summary of an Ongoing Independent Inquiry into Canadian Native "Residential Schools" and Their Legacy (Vancouver: The Truth Commission into Genocide in Canada, 2001).

18. Patricia Monture-Angus, Journeying Forward: Dreaming First Nations' Independence (Halifax: Fernwood Publishing, 1999); Celia Haig-Brown, Resistance and Renewal: Surviving the Indian Residential School (Vancouver: Tillicum Library, 1988).

19. Eduardo Duran, Native American Postcolonial Psychology (Albany: State University of New York Press, 1995).

20. Peter Kulchyski, "Aboriginal Peoples and Hegemony in Canada," Journal of Canadian Studies 30 (1995): 60-68.

21. Calder v. British Columbia (A.G.) (1973), 34 D.L.R. (3d) 145, [1973] S.C.R. 313, [1973] 4 W.W.R. 1.

22. Each of these developments, however, was limited in terms of the justice offered to Aboriginal peoples. The comprehensive land-claims process is very onerous for Aboriginal groups; see Gurston Dacks, "The Politics of Native Claims in Northern Canada," in The Quest for Justice: Aboriginal Peoples and Aboriginal Rights, ed. Menno Boldt and J.A. Long, 251-64 (Toronto: University of Toronto Press, 1985). The Constitution Act, 1982, provides Aboriginals with only an "empty box" of rights- the nature of these rights and of Aboriginal title are still yet to be fully determined; see Douglas Sanders, "Preexisting Rights: The Aboriginal Peoples of Canada (Sections 25 and 35)," in The Canadian Charter of Rights and Freedoms, 3rd ed., ed. G.-A. Beaudoin and E.I. Mendes, 232-60 (Scarborough, ON: Carswell, 1995).

23. Miller, Skyscrapers Hide the Heavens.

24. Samantha Power, "A Problem from Hell": America and the Age of Genocide (New York: Basic Books, 2002), 17.

25. Chalk and Jonassohn, History and Sociology of Genocide; Samuel Totten, William S. Parsons, and Robert K. Hitchcock "Confronting Genocide and Ethnocide of Indigenous 
Peoples: An Interdisciplinary Approach to Definition, Intervention, Prevention, and Advocacy," in Annihilating Difference: The Anthropology of Genocide, ed. Alexander Laban Hinton, 54-91 (Berkeley: University of California Press, 2002).

26. Ward Churchill, Perversions of Justice: Indigenous Peoples and Angloamerican Law (San Francisco: City Lights Books, 2003).

27. See, e.g., Dirk A. Moses, "Conceptual Blockages and Definitional Dilemmas in the 'Racial Century': Genocides of Indigenous Peoples and the Holocaust," Patterns of Prejudice 36, 4 (2002): 7-36.

28. This aspect of Lemkin's work was similarly emphasized by the Australian inquiry into the separation of Aboriginal and Torres Strait Islander children from the families. See Human Rights and Equal Opportunity Commission, Bringing Them Home: Report of the National Inquiry into the Separation of Aboriginal and Torres Strait Islander Children from Their Families (Sydney: Sterling Press, 1997).

29. Raphael Lemkin, Axis Rule in Occupied Europe: Laws of Occupation, Analysis of Government, Proposals for Redress (Washington, DC: Carnegie Endowment for International Peace, 1944), 79.

30. Chalk and Jonassohn, History and Sociology of Genocide, 23.

31. See, e.g., Robert van Krieken, "Rethinking Cultural Genocide: Aboriginal Child Removal and Settler-Colonial State Formation," Oceania 75 (2004): 125-50.

32. UNCG, art. 2. The UNCG entered into force on 12 January 1951.

33. Several scholars have noted that the political negotiations surrounding the UNCG shifted it away from Lemkin's intentions. See, e.g., Leo Kuper, Genocide: Its Political Use in the Twentieth Century (New Haven, CT: Yale University Press, 1981).

34. See Alexander Laban Hinton, "The Dark Side of Modernity: Toward an Anthropology of Genocide," in Annihilating Difference: The Anthropology of Genocide, ed. Alexander Laban Hinton, 1-40 (Berkeley: University of California Press, 2002).

35. See, e.g., the resistance to assumptions of ethnic homogeneity among the Tsleil-Waututh of British Columbia. Tsleil Waututh First Nation, Our Land to Share: A Future for the People of the Inlet: A Comprehensive Approach to Settling an Urban First Nation Treaty in British Columbia (Vancouver: Tsleil Waututh First Nation, 2000).

36. Brian Thom, "The Paradox of Boundaries in Coast Salish Territories" (paper presented at Indigenous Cartographies and Representational Politics: An International Conference Dedicated to the Critical Examination of Indigenous Mapping and Geographic Information Systems, Cornell University, Ithaca, NY, 3-5 March 2006); Monture-Angus, Journeying Forward.

37. Peter Kulchyski, Like the Sound of a Drum: Aboriginal Cultural Politics in Denendeh and Nunavut (Winnipeg: University of Manitoba Press, 2005); Jean-Luc Nancy, The Inoperative Community (Minneapolis: University of Minnesota Press, 1991); Giorgio Agamben, The Coming Community (Minneapolis: University of Minnesota Press, 1993).

38. See, e.g., Taiaiake Alfred, Peace, Power, Righteousness: An Indigenous Manifesto (London: Oxford University Press, 1999).

39. Dean Neu and Richard Therrien, Accounting for Genocide: Canada's Bureaucratic Assault on Aboriginal People. (Black Point, NS: Fernwood Publishing/Zed Books, 2002); Katherine Bischoping and Natalie Fingerhut, "Border Lines: Indigenous Peoples in Genocide Studies," Canadian Review of Sociology and Anthropology 33 (1996): 481-506.

40. Cole Harris, Making Native Space: Colonialism, Resistance and Reserves in British Columbia (Vancouver: UBC Press, 2002), 291.

41. As noted above, whereas the Canadian government signed treaties with most Aboriginal groups, in several regions of the country such agreements were not a feature of colonialism (e.g., B.C., Yukon, and parts of Quebec). However, even those Aboriginal groups that did sign treaties found themselves facing unexpected assaults on their territory and their traditional land-based practices as these agreements were violated or manipulated. See Ray et al., Bounty and Benevolence.

42. Kulchyski, Like the Sound of a Drum, 18. 
43. Monture-Angus, Journeying Forward, 56.

44. Julie Cruickshank, The Social Life of Stories: Narratives and Knowledge in the Yukon Territory (Lincoln: University of Nebraska Press, 1998); Thom, "Paradox of Boundaries."

45. Thom, "Paradox of Boundaries," 21-22.

46. It should be remembered that part of the colonial project in Canada was to homogenize Aboriginal peoples under a single term, "Indian," and thus to make them governable as a unitary people.

47. Bruno Latour, We Have Never Been Modern (Cambridge, MA.: Harvard University Press, 1993).

48. Ibid.

49. This, of course, excludes purposeful uses of disease as a form of "biological warfare" against Aboriginal combatants. See Elizabeth A. Fenn, "Biological Warfare in Eighteenth-Century North America: Beyond Jeffrey Amherst," Journal of American History 86 (2000): 1552-80.

50. Daniel W. Clayton, Islands of Truth: The Imperial Fashioning of Vancouver Island (Vancouver: UBC Press, 2000).

51. Bruce G. Trigger, Natives and Newcomers: Canada's "Historic Age" Reconsidered (Kingston: McGill-Queen's University Press, 1985).

52. Annett, Hidden from History.

53. Anastasia Shkilnyk, A Poison Stronger Than Love: The Destruction of an Ojibwa Community (New Haven, CT: Yale University Press, 1985).

54. Another instructive example involves the smallpox epidemic in Victoria, BC, in 1862. Aboriginal persons camping near the city to take advantage of trade were infected by a strain of smallpox that likely originated in San Francisco and was carried northward through the gold rush. After some efforts to quarantine and vaccinate those infected, the colonial government resorted to expelling the Aboriginal persons through the deployment of gunboats. These individuals returned to their communities, carrying the deadly disease with them. See Barry M. Gough, Gunboat Frontier: British Maritime Authority and Northwest Coast Indians, 1846-90 (Vancouver: UBC Press, 1984).

55. Michael A. McDonnell and Dirk A. Moses, "Raphael Lemkin as Historian of Genocide in the Americas," Journal of Genocide Research 7 (2005): 201-29.

56. For more thorough discussion of the question of intent as it relates to Aboriginal peoples see Moses, "Conceptual Blockages and Definitional Dilemmas" Dirk A. Moses, "An Antipodean Genocide? The Origins of the Genocidal Moment in the Colonization of Australia," Journal of Genocide Research 2 (2000): 89-106; Tony Barta, "Relations of Genocide: Land and Lives in the Colonization of Australia," in Genocide and the Modern Age: Etiology and Case Studies of Mass Death, ed. Isador Wallimann and Michael N. Dobkowski, 237-52 (Syracuse, NY: Syracuse University Press, 1987).

57. John S. Milloy, A National Crime: The Canadian Government and the Residential School System, 1879 to 1986 (Winnipeg: University of Manitoba Press, 1999).

58. Alan C. Cairns, Citizens Plus: Aboriginal Peoples and the Canadian State (Vancouver: UBC Press, 2000).

59. Quoted in Milloy, A National Crime, 33-4.

60. Quoted in Brian E. Titley, A Narrow Vision: Duncan Campbell Scott and the Administration of Indian Affairs in Canada (Vancouver: UBC Press, 1986), 50; see also Neu and Therrien, Accounting for Genocide.

61. Milloy, A National Crime, 37.

62. Lemkin writes that "genocide has two phases: one, destruction of the national pattern of the oppressed group; the other, the imposition of the national pattern of the Oppressor." Lemkin, Axis Rule in Occupied Europe, 79. One gets the sense that not only is assimilation a key component of the definition of genocide, it is a twin process to extermination, which is often the privileged focus of genocide studies. As Michael McDonnell and Dirk Moses note, this passage illustrates that genocide "is colonial in nature," since it shows imperialist 
ambitions to be at the heart of genocidal processes. McDonnell and Moses, "Raphael Lemkin as Historian," 501.

63. van Krieken, "Rethinking Cultural Genocide," 141.

64. See Annett, Hidden from History; Churchill, "Forbidding the 'G-Word"; Robert Davis and Mark Zannis, The Genocide Machine in Canada: The Pacification of the North (Montreal: Black Rose Books, 1973); Neu and Therrien, Accounting for Genocide. 